NBER WORKING PAPER SERIES

THE FORWARD MARKET IN EMERGING CURRENCIES:

LESS BIASED THAN IN MAJOR CURRENCIES

\author{
Jeffrey Frankel \\ Jumana Poonawala \\ Working Paper 12496 \\ http://www.nber.org/papers/w12496
}

\begin{abstract}
NATIONAL BUREAU OF ECONOMIC RESEARCH
1050 Massachusetts Avenue

Cambridge, MA 02138
\end{abstract}

August 2006

The authors would like to thank Janice Boucher Breuer for comments. The views expressed herein are those of the author(s) and do not necessarily reflect the views of the National Bureau of Economic Research.

(C)2006 by Jeffrey Frankel and Jumana Poonawala. All rights reserved. Short sections of text, not to exceed two paragraphs, may be quoted without explicit permission provided that full credit, including (C notice, is given to the source.

The Forward Market in Emerging Currencies: Less Biased than in Major Currencies 
Jeffrey Frankel and Jumana Poonawala

NBER Working Paper No. 12496

August 2006

JEL No. F0, F15, F31

\begin{abstract}
Many studies have replicated the finding that the forward rate is a biased predictor of the future change in the spot exchange rate. Usually the forward discount actually points in the wrong direction. But virtually all those studies apply to advanced economies and major currencies. We apply the same tests to a sample of 14 emerging market currencies. We find a smaller bias than for advanced country currencies. The coefficient is on average positive, i.e., the forward discount at least points in the right direction. It is never significantly less than zero. To us this suggests that a time-varying exchange risk premium may not be the explanation for traditional findings of bias. The reasoning is that emerging markets are probably riskier; yet we find that the bias in their forward rates is smaller. Emerging market currencies probably have more easily-identified trends of depreciation than currencies of advanced countries.
\end{abstract}

Jeffrey Frankel

Kennedy School of Government

Harvard University

79 JFK Street

Cambridge, MA 02138

and NBER

jeffrey frankel@harvard.edu

Jumana Poonawala

1500 Chestnut Street

Apt 15B

Philadelphia, PA 19102

jumana@post.harvard.edu 


\title{
The Forward Market in Emerging Currencies: Less Biased than in Major Currencies
}

\author{
Jeffrey Frankel and Jumana Poonawala
}

Thirty years ago, researchers found the forward exchange rate to be a biased predictor of the future spot exchange rate. Worse, in a regression of the future change in the spot rate against the forward discount, the exchange rate was found on average to move in precisely the opposite direction from what was predicted. ${ }^{1}$ This surprising finding has been replicated many times since, on many sets of data, and with many refinements. But virtually all the tests have been applied to major currencies and industrialized countries, not to currencies of developing countries. By now enough emerging market currencies are represented by forward markets that it is possible to apply the same tests to them. ${ }^{2}$

\section{Introduction: Tests of Bias in the Forward Discount}

Although many explanations have been given for the finding of bias in the forward market, they fall broadly into two categories. The first category of explanations, to which an apparent majority of authors subscribe, maintains the assumption of rational expectations, and interpret the systematic component of the forward market's prediction errors as a risk premium. The second category attributes the systematic component of the forward rate's prediction errors to expectation errors on the part of market participants that are themselves systematic, at least within the sample. ${ }^{3}$ Algebraically, the regression equation is:

where

$$
\Delta s_{t+1}=\alpha+\beta f d_{t}+\varepsilon_{t+1},
$$

$$
\Delta s_{t+1} \text { is ex post future percentage depreciation, defined as } s_{t+1}-s_{t},
$$

\footnotetext{
1 The first tests included Rogoff (1977), Hansen and Hodrick (1980), and Frankel (1980); they included consideration of two problems of the error term distribution: moving average errors (from overlapping contracts) and non-normal distributions (from the "peso problem"). Tryon (1997) was the first to run the regression in the form of changes relative to the contemporaneous spot rate, and Fama (1984) made this specification famous. Useful surveys of the literature include Hodrick (1987), Froot and Thaler (1990), Engel (1995) and Lewis (1995). More recent contributions to the literature include Bacchetta and van Wincoop (2005), Backus, Foresi and Telmer (2002), Breuer (2000), Lustig and Verdelhan (2005) and Verdelhan (2006).

${ }^{2}$ Bansal and Dahlquist (2000) test whether the interest differential for developing countries is an unbiased forecast of future exchange rate changes. Similarly, Flood and Rose (2002) find that the bias in the interest differential is less for crisis countries, while not significantly different between developed versus developing. But one cannot invoke covered interest parity, and thereby associate such findings with forward rate bias, in the same way one could for advanced countries. The reason is that many of these countries have capital controls, default risk, and interest rates that are not freely determined in the marketplace.

${ }^{3}$ This phrasing is intended to be broad enough to include the peso problem, learning, and other sources of error patterns that appear statistically significant within the sample. The definition need not imply that market participants are irrational.
} 
$f d_{t}$ is the forward discount, of a maturity matching that of the ex post depreciation, defined as $f_{t}-s_{t}$,

$s_{t} \equiv \log$ of the spot exchange rate at time $t$ (defined as domestic units per foreign), and

$f_{t} \equiv \log$ of the forward exchange rate at time $t$.

The null hypothesis of unbiasedness is $\beta=1$. The null would imply that there is no systematic time-varying component to the prediction errors:

$$
E_{t} \Delta s_{t+1}-f d_{t}=\alpha
$$

The null hypothesis is actually a joint hypothesis, comprising of two distinct conditions: rational expectations: $\quad E_{t} \Delta s_{t+1}=\Delta s_{t}{ }^{e}, \quad$ plus no time-varying risk premium: $r p_{t} \equiv E_{t} \Delta s_{t+1}-f d_{t}-\alpha=0$,

where $E_{t} \Delta s_{t+1}$ is the mathematical expectation (within-sample), and $\Delta s_{t}{ }^{e}$ is the expectation held by investors.

$\varepsilon_{t+1}$ is the error term, which would be equal to the forward market prediction error under the null hypothesis. But the null hypothesis is almost always rejected statistically, and often the finding is $\beta<0$. The question then becomes whether the findings of bias are to be interpreted as a time-varying risk premium, or as systematic expectation errors.

The simple purpose of this paper is to test for bias in the forward markets in emerging market currencies, and to see how the bias compares to that for major currencies. One motivation is to shed some possible light on the two competing interpretations of bias. Intuitively, emerging market currencies are probably riskier to hold than major currencies; one might think that the risk premium would therefore be larger and more variable than for major currencies. At the same time, emerging market currencies are more prone to bouts of high inflation and other sources of medium-term trends, so that one might think it would be easier to forecast the direction of movement of the spot rate than is the case for major currencies, where the exchange rate is closer to a random walk. ${ }^{4}$ If the bias is greater for emerging market currencies, that would point toward the risk premium interpretation; if less, then the other interpretation. We hasten to add that this suggested motivation is not demonstrated on the basis of formal theory. It would be hard to do so. It would not be easy, for example, to rule out the possibility that even though emerging market currencies have higher variance, their risk is highly diversifiable so that the risk premium could in theory go the other way. ${ }^{5}$ However, there is a bit of evidence, from survey data, that investors indeed find it easier to forecast the direction of movement of emerging market currencies than of major currencies. ${ }^{6}$

In the financial markets, efforts to exploit the forward discount bias generally go under different-sounding names. Exploiting the bias means "going long" in the currency that sells at a forward discount, relative to others. By covered interest parity, this is the same thing as going long in the currency that pays a higher short-term nominal interest rate, relative to others. Among European currencies in the early 1990s -- with

\footnotetext{
${ }^{4}$ Huisman, Koedijk, Kool, and Nissen (1998) find less bias in periods when the forward discount or premium is large.

${ }^{5}$ Poonawala (2004).

${ }^{6}$ Chinn and Frankel $(1994,2002)$.
} 
Italian interest rates, for example, above German interest rates -- this strategy was known as the convergence play. The convergence play may again be relevant for Central European currencies hoping to join the euro. In the mid-1990s, with Japanese interest rates very low, the strategy of borrowing in yen and going long in other currencies -especially dollar-linked currencies in Asia -- was known as the yen carry trade. One striking pattern about these episodes is that there are long intervals during which one would have happily made money on average with these strategies, but that these intervals were dramatically punctuated (though not fully reversed) by crises, in 1992 in Europe and 1997-98 in Asia. During the years 2001-2006, with US interest rates low, the strategy of borrowing in dollars and going long in euros or emerging market currencies has been known as the dollar carry trade. Again, all these strategies are equivalent to attempts to exploit the finding of forward discount bias, which constitutes another motivation for testing to see whether the finding extends equally to emerging market currencies.

The paper examines forward markets for 35 currencies, classified under the two broad groupings of emerging market currencies versus the currencies of advanced economies countries (including 11 European Monetary Union countries). The data set starts from December 31, 1996, and runs into 2004.

Our results show that the bias in the forward discount for emerging market economies is smaller than for advanced economies. While we reproduce the standard finding that the coefficient is substantially less than zero for industrialized economies, and generally highly significant statistically, we find that the coefficient is much closer to zero for emerging market currencies: often positive and seldom significantly less than zero. To us the fact that the bias is stronger for advanced country currencies, which are presumably more stable, suggests that it may not be entirely due to an exchange risk premium.

\section{The Data Sample}

Although many national money markets have been liberalized since the 1970s, there is still only a relatively limited set of currencies in which forward exchange contracts are actively traded by international investors. Thus Asia is more heavily represented in our sample than Latin America or, certainly, Africa. Countries in our analysis have been classified as emerging market economies based on the IMF Country Grouping Classification. ${ }^{7}$ These also include some countries that are classified by the IMF as newly industrialized economies: Hong Kong, Singapore and Taiwan.

Our regression analysis proceeds first country by country, and then pooled. We start in December 1996 because data are not available for enough emerging markets before then. We use Seemingly Unrelated Regressions (SUR) to correct for the likely correlation of the error term across currencies.

In order to understand the impact of the Asian Financial Crisis, two sets of regressions have been conducted: one includes the period of financial crisis, while the other does not. The results from the regression analysis starting December 1996 onwards are presented in Section three. Regression results for post Asian financial crises (from December 1998 onwards) are reported in the Appendix.

\footnotetext{
${ }^{7}$ See Appendix I for more details on data set.
} 
Some in our sample never experienced a large change in the exchange rate. Some countries with tightly fixed exchange rates were not included in the analysis. But if we had left out specifically all those emerging market currencies that had relatively stable currencies during the sample period, it might have biased the sample in favor of volatile emerging market currencies. (Hong Kong has been included; there is a small band which allows some room for movement even though it has a currency board.) Countries with capital controls (India) are not excluded from our sample. An established forward market in these countries shows that there exists a demand for forward exchange transactions. We have 14 currencies classified as emerging. Data details are given in the appendix. $^{8}$

As has long been recognized in this literature, the use of overlapping contracts (3month forward contracts observed at a one-month frequency) creates a moving average error process. We address this problem in the simplest way possible: by using nonoverlapping contracts. Our data are sampled at the same frequency as the horizon of the forward exchange rate -- one month. It is necessary to avoid 'mismatching' which would involve incorrect pairing of the forward exchange rate and the future spot rate to which it pertains. Specifically, we use the forward and spot exchange rates from the last working day of each month. ${ }^{9}$ (Raw data series are reported in Appendix VI of the 2004 working paper: http://ksghome.harvard.edu/ jfrankel/currentpubsspeeches.htm\#On\%20Emerging\%20Markets.)

\section{Results Country by Country}

We begin with the country by country regression results, presented in Table 1. The scatter plots for each country are illustrated in Figures 1 and 2. To repeat the regression equation,

$$
\mathrm{s}_{\mathrm{t}+1}-\mathrm{s}_{\mathrm{t}}=\alpha+\beta\left(\mathrm{f}_{\mathrm{t}}-\mathrm{s}_{\mathrm{t}}\right)+\varepsilon_{\mathrm{t}+1}
$$

The results confirm the usual finding of a strong forward rate bias for most of the industrialized country currencies. All the currencies except for the Greek drachma and Japanese yen show coefficients that are statistically less than one at very high significance levels. Most of the advanced countries show coefficients that are also significantly less than zero at the 5\% level. Only Canada, Greece, Italy, Japan and the UK are not significant at the 5\% level. Thus we can reject the hypotheses that the coefficient $\beta$ is zero for sixteen of the twenty-one advanced economies, and we can also reject the hypotheses that $\beta=1$ for nineteen of the twenty-one countries in our advanced country sample.

\footnotetext{
${ }^{8}$ Indonesia, where the end-date of available forward exchange rate data does not coincide with the data-sets available for other countries was included in individual country regressions, but was dropped from the pooled regression.

${ }^{9}$ Breuer and Wohar (1996) identify timing pitfalls, and suggest that they can be reduced by taking data from the middle of the month instead of the end.
} 


\section{Country By Country Analysis}

TABLE I: Individual Advanced Country Regressions (12/31/96 - 04/30/2004) Coefficients with Robust Standard Errors (Forecast Horizon is One Month)

\begin{tabular}{|c|c|c|c|c|c|c|c|}
\hline & Dates & $\boldsymbol{N}$ & $\beta(S . E)$. & $t: \beta=0$ & $t: \beta=1$ & $D W$ & F Prob \\
\hline \multicolumn{8}{|l|}{ Advanced Economies } \\
\hline 1. Australia & $12 / 96-4 / 04$ & 88 & $\begin{array}{l}-5.6437 \\
(2.1666)\end{array}$ & -2.60 & 9.40 & 1.95 & 0.0108 \\
\hline 2. Austria & $12 / 96-4 / 04$ & 88 & $\begin{array}{c}-5.2804 \\
(1.9551)\end{array}$ & -2.70 & 10.32 & 1.75 & 0.0083 \\
\hline 3. Belgium & $12 / 96-4 / 04$ & 88 & $\begin{array}{c}-5.5236 \\
(1.9642)\end{array}$ & -2.81 & 11.03 & 1.75 & 0.0061 \\
\hline 4. Canada & $12 / 96-4 / 04$ & 88 & $\begin{array}{c}-3.2183 \\
(1.8926) \\
\end{array}$ & -1.70 & 4.97 & 1.96 & 0.0927 \\
\hline 5. Denmark & $12 / 96-4 / 04$ & 88 & $\begin{array}{c}-5.5150 \\
(2.0319) \\
\end{array}$ & -2.71 & 10.28 & 1.76 & 0.0080 \\
\hline 6. $\quad$ Euro & $12 / 96-4 / 04$ & 86 & $\begin{array}{c}-5.6024 \\
(2.0813) \\
\end{array}$ & -2.69 & 10.06 & 1.81 & 0.0086 \\
\hline 7. Finland & $12 / 96-4 / 04$ & 88 & $\begin{array}{c}-5.4680 \\
(1.9057) \\
\end{array}$ & -2.87 & 11.52 & 1.78 & 0.0052 \\
\hline 8. France & $12 / 96-4 / 04$ & 88 & $\begin{array}{l}-5.1522 \\
(1.9419)\end{array}$ & -2.65 & 10.04 & 1.74 & 0.0095 \\
\hline 9. Germany & $12 / 96-4 / 04$ & 88 & $\begin{array}{c}-5.2964 \\
(1.9384) \\
\end{array}$ & -2.73 & 10.55 & 1.75 & 0.0076 \\
\hline 10. Greece & $12 / 96-4 / 04$ & 88 & $\begin{array}{c}2.4052 \\
(2.0348)\end{array}$ & 1.18 & 0.48 & 1.77 & 0.2405 \\
\hline 11. Ireland & $12 / 96-4 / 04$ & 88 & $\begin{array}{c}-5.6322 \\
(2.1612) \\
\end{array}$ & -2.61 & 9.42 & 1.77 & 0.0108 \\
\hline 12. Italy & $12 / 96-4 / 04$ & 88 & $\begin{array}{c}-3.6422 \\
(2.2115) \\
\end{array}$ & -1.65 & 4.41 & 1.66 & 0.1032 \\
\hline 13. Japan & $12 / 96-4 / 04$ & 88 & $\begin{array}{c}-1.2805 \\
(2.0472) \\
\end{array}$ & -0.63 & 1.24 & 2.14 & 0.5333 \\
\hline 14. Netherlands & $12 / 96-4 / 04$ & 88 & $\begin{array}{c}-5.1816 \\
(1.9166) \\
\end{array}$ & -2.70 & 10.40 & 1.76 & 0.0083 \\
\hline 15. New Zealand & $12 / 96-4 / 04$ & 88 & $\begin{array}{c}-3.9942 \\
(2.0142) \\
\end{array}$ & -1.98 & 6.15 & 1.62 & 0.0506 \\
\hline 16. Norway & $12 / 96-4 / 04$ & 88 & $\begin{array}{c}-3.8507 \\
(1.4636)\end{array}$ & -2.63 & 10.98 & 2.18 & 0.0101 \\
\hline 17. Portugal & $12 / 96-4 / 04$ & 88 & $\begin{array}{c}-4.4242 \\
(2.1870)\end{array}$ & -2.02 & 6.15 & 1.69 & 0.0462 \\
\hline 18. Spain & $12 / 96-4 / 04$ & 88 & $\begin{array}{c}-4.8614 \\
(2.2027) \\
\end{array}$ & -2.21 & 7.08 & 1.68 & 0.0300 \\
\hline 19. Sweden & $12 / 96-4 / 04$ & 88 & $\begin{array}{c}-5.5293 \\
(1.8184) \\
\end{array}$ & -3.04 & 12.89 & 2.01 & 0.0031 \\
\hline 20. Switzerland & $12 / 96-4 / 04$ & 88 & $\begin{array}{c}-4.3037 \\
(2.0588) \\
\end{array}$ & -2.09 & 6.64 & 1.85 & 0.0395 \\
\hline 21. UK & $12 / 96-4 / 04$ & 88 & $\begin{array}{c}-3.9999 \\
(2.8715) \\
\end{array}$ & -1.39 & 3.03 & 2.10 & 0.1673 \\
\hline
\end{tabular}


TABLE II:

Individual Emerging Market Country Regressions (12/31/96-04/30/2004)

Coefficients with Robust Standard Errors. Forecast Horizon is One Month.

\begin{tabular}{|c|c|c|c|c|c|c|c|}
\hline & Dates & $N$ & $\beta(S . E)$. & $t: \beta=0$ & $t: \beta=1$ & $D W$ & F Prob \\
\hline \multicolumn{8}{|c|}{ Emerging and Newly Industrialized Economies } \\
\hline 1. Czech Republic & $12 / 96-4 / 04$ & 88 & $\begin{array}{c}0.4260 \\
(0.6604)\end{array}$ & 0.65 & 0.76 & 1.90 & 0.5206 \\
\hline 2. Hong Kong & $12 / 96-4 / 04$ & 88 & $\begin{array}{l}-0.0439 \\
(0.0376)\end{array}$ & -1.17 & 768 & 2.44 & 0.2468 \\
\hline 3. Hungary & $10 / 97-4 / 04$ & 78 & $\begin{array}{c}0.7541 \\
(1.2594)\end{array}$ & 0.60 & 0.04 & 1.82 & 0.5511 \\
\hline 4. India & $10 / 97-4 / 04$ & 78 & $\begin{array}{l}-0.6181 \\
(0.8612)\end{array}$ & -0.72 & 3.53 & 1.43 & 0.4751 \\
\hline 5. Indonesia & $12 / 96-12 / 02$ & 73 & $\begin{array}{c}0.1456 \\
(0.2055)\end{array}$ & 0.71 & 17.28 & 1.55 & 0.4807 \\
\hline 6. $\quad$ Kuwait & $12 / 96-4 / 04$ & 88 & $\begin{array}{c}0.4050 \\
(0.9394)\end{array}$ & 0.43 & 0.40 & 1.89 & 0.6674 \\
\hline 7. Mexico & $12 / 96-4 / 04$ & 88 & $\begin{array}{c}-0.6399 \\
(0.4079)\end{array}$ & -1.57 & 16.16 & 1.99 & 0.1204 \\
\hline 8. Philippines & $12 / 96-4 / 04$ & 88 & $\begin{array}{c}1.6770 \\
(1.7128)\end{array}$ & 0.98 & 0.16 & 1.87 & 0.3303 \\
\hline 9. $\quad$ Saudi Arabia & $12 / 96-4 / 04$ & 88 & $\begin{array}{c}-0.0831 \\
(0.0835)\end{array}$ & -1.00 & 168.17 & 2.94 & 0.3223 \\
\hline 10. Singapore & $12 / 96-4 / 04$ & 88 & $\begin{array}{c}0.1911 \\
(1.2898)\end{array}$ & 0.15 & 0.39 & 1.86 & 0.8826 \\
\hline 11. South Africa & $12 / 96-4 / 04$ & 88 & $\begin{array}{l}-3.2693 \\
(1.8403)\end{array}$ & -1.78 & 5.38 & 1.74 & 0.0792 \\
\hline 12. Taiwan & $12 / 96-4 / 04$ & 88 & $\begin{array}{c}0.1442 \\
(0.5252)\end{array}$ & 0.27 & 2.65 & 1.75 & 0.7842 \\
\hline 13. Thailand & $12 / 96-4 / 04$ & 88 & $\begin{array}{c}0.9613 \\
(0.6853)\end{array}$ & 1.40 & 0.00 & 1.62 & 0.1643 \\
\hline 14. Turkey & $12 / 96-4 / 04$ & 88 & $\begin{array}{c}-0.0031 \\
(0.0284)\end{array}$ & -0.11 & 1241 & 1.54 & 0.9133 \\
\hline
\end{tabular}

Note on DW Stat: For the test of null hypotheses (no autocorrelation) at the 5\% significance level, the appropriate $\mathrm{dL}$ and $\mathrm{dU}$ critical values for 80 to 99 observations and one explanatory variable are 1.61 and 1.66 respectively. I.e., we reject if $\mathrm{d}<1.61$ and do not reject if $\mathrm{d}>1.66$. For 60 to 79 observations, $\mathrm{dL}=1.55$ and $\mathrm{dU}=1.62$ 


\begin{tabular}{|c|c|c|c|c|c|}
\hline & $\mathrm{I}$ & Coef. & Std. Err. & $\mathrm{z}$ & $\mathrm{P}>|z|$ \\
\hline \multicolumn{6}{|c|}{ Advanced Economies } \\
\hline Australia & 1 & -1.24691 & 1.494352 & -0.83 & 0.404 \\
\hline Canada & I & -0.010953 & 1.738178 & -0.01 & 0.995 \\
\hline Denmark & । & -2.189826 & 0.623724 & -3.51 & 0.000 \\
\hline European Union & । & -2.258394 & 0.624710 & -3.62 & 0.000 \\
\hline Japan & । & 1.032035 & 1.463353 & 0.71 & 0.481 \\
\hline New Zealand & । & -1.607774 & 1.337827 & -1.20 & 0.229 \\
\hline Norway & । & -2.331581 & 0.768280 & -3.03 & 0.002 \\
\hline Sweden & I & -2.190423 & 0.887877 & -2.47 & 0.014 \\
\hline Switzerland & । & -1.998467 & 0.799680 & -2.50 & 0.012 \\
\hline UK & । & -2.040146 & 1.755574 & -1.16 & 0.245 \\
\hline \multicolumn{6}{|c|}{ Emerging and Newly Industrialized Economies } \\
\hline Czech Republic & I & -0.268865 & 0.625856 & -0.43 & 0.667 \\
\hline Hong Kong & । & -0.025843 & 0.054466 & -0.47 & 0.635 \\
\hline Hungary & । & -0.628215 & 0.642181 & -0.98 & 0.328 \\
\hline India & । & -0.598888 & 0.542740 & -1.10 & 0.270 \\
\hline Kuwait & । & 0.897000 & 0.409053 & 2.19 & 0.028 \\
\hline Mexico & । & -0.863151 & 0.406361 & -2.12 & 0.034 \\
\hline Philippines & । & -0.758016 & 0.701212 & -1.08 & 0.280 \\
\hline Saudi Arabia & । & -0.070964 & 0.027124 & -2.62 & 0.009 \\
\hline Singapore & । & 0.174195 & 0.625553 & 0.28 & 0.781 \\
\hline South Africa & । & -1.638586 & 1.470407 & -1.11 & 0.265 \\
\hline Taiwan & । & 0.325223 & 0.410904 & 0.79 & 0.429 \\
\hline Thailand & । & -0.914912 & 0.465787 & -1.96 & 0.050 \\
\hline Turkey & । & -0.028603 & 0.025821 & -1.11 & 0.268 \\
\hline
\end{tabular}

\footnotetext{
${ }^{10}$ Does not include Euro member countries (to avoid overlap of data with the Euro) and Indonesia (end date of available forward exchange rate data does not coincide with the data-sets available for the remaining countries)
} 


\begin{tabular}{|c|c|c|c|c|c|}
\hline Equation & $\mathrm{Obs}$ & RMSE & $\mathrm{R}^{2}$ & $x^{2}$ & P \\
\hline ausspot & 78 & .03192 & 0.0273 & .6962491 & 0.4040 \\
\hline canspot & 78 & .01854 & 0.0002 & .0000397 & 0.9950 \\
\hline dnkspot & 78 & .02658 & 0.0460 & 12.32631 & 0.0004 \\
\hline euspot & 78 & .02652 & 0.0522 & 13.069 & 0.0003 \\
\hline jpnspot & 78 & .03639 & -0.0074 & .4973826 & 0.4807 \\
\hline nzlspot & 78 & .03284 & 0.0275 & 1.444276 & 0.2294 \\
\hline norspot & 78 & .02734 & 0.0629 & 9.210043 & 0.0024 \\
\hline swespot & 78 & .02688 & 0.0677 & 6.086248 & 0.0136 \\
\hline sfrspot & 78 & .02711 & 0.0359 & 6.24541 & 0.0125 \\
\hline ukspot & 78 & .02069 & 0.0243 & 1.350468 & 0.2452 \\
\hline czespot & 78 & .03500 & 0.0004 & .1845529 & 0.6675 \\
\hline hkspot & 78 & .00099 & 0.0009 & .2251411 & 0.6352 \\
\hline hunspot & 78 & .02905 & -0.0108 & .956976 & 0.3279 \\
\hline indspot & 78 & .01182 & 0.0111 & 1.217607 & 0.2698 \\
\hline kwtspot & 78 & .00404 & -0.0066 & 4.808668 & 0.0283 \\
\hline mexspot & 78 & .02540 & 0.0186 & 4.5118 & 0.0337 \\
\hline phlspot & 78 & .03091 & -0.0018 & 1.168581 & 0.2797 \\
\hline sauspot & 78 & .00012 & 0.0791 & 6.844601 & 0.0089 \\
\hline sgpspot & 78 & .01874 & 0.0001 & .0775434 & 0.7807 \\
\hline safspot & 78 & .04655 & 0.0296 & 1.241833 & 0.2651 \\
\hline taispot & 78 & .01624 & 0.0005 & .6264454 & 0.4287 \\
\hline thaspot & 78 & .04131 & -0.0060 & 3.858198 & 0.0495 \\
\hline turspot & 78 & .05804 & -0.0049 & 1.227079 & 0.2680 \\
\hline
\end{tabular}

Our key result first appears in Table 2: the emerging market economies have coefficients that are generally less negative than their developed country counterparts. Somewhat more of them are greater than zero than negative. The average coefficient for emerging market economies is also positive: 0.0033, versus -4.3331 for advanced economies. To be sure, the forward market is still a biased predictor for more than half of the emerging currencies: we can easily reject the hypothesis that the coefficient is 1.0 for eight of the fourteen emerging market economies (Hong Kong, India, Indonesia, Mexico, Saudi Arabia, South Africa, Taiwan and Turkey). But in none of the emerging market currencies is the coefficient statistically less than zero at the 5\% significance level.

Thus far the results support a significant difference between the results of the industrialized economies and the emerging markets. That the absolute values for emerging markets are smaller suggests that the forward exchange rate is a less biased indicator for the future expected spot rate in emerging market economies. ${ }^{11}$

Next, in Table III, we correct for correlation of the error term across countries in the error term, using the technique of Seemingly Unrelated Regressions (SUR). ${ }^{12}$ The SUR analysis starts from October 1997, which is the starting point for India and Hungary in our dataset, so as to standardize the number of observation dates. Therefore all currencies have 78 data points.

\footnotetext{
${ }^{11}$ Appendix 5 presents the regressions results for the data set not including the turbulent period covering the Asian Financial crisis.

${ }^{12}$ Such a correlation is almost inevitable when using bilateral exchange rates. For example, a strong dollar or a contagious currency crisis in a particular month would likely show up across many of the bilateral dollar exchange rates.
} 
Except for South Africa, and Canada and Japan, which appear as outliers in their sets -- emerging market economies and advanced economies respectively -- the emerging markets under SUR all continue to yield coefficient estimates that are less negative than all the industrialized economies. Among advanced currencies, 5 of 10 show coefficients that are clearly significantly less than zero, while among emerging markets only 2 of 14 do so (Mexico and South Africa).

\section{Results from Pooled Analysis}

We next attempt, in Table IV, to capture more information from our data set by running a pooled country regression analysis with all currencies constrained to have the same coefficient within each class of countries. The pooled analysis lets us bring all the data to bear at once to get the best estimator. We keep separate pools for the emerging market economies and the industrialized economies. (See Figure 3.) To eliminate double counting of observations, only the Euro has been included in the pooled analysis for industrialized economies; individual EMU member countries have been excluded. This brings the number of advanced countries included in the pooled regression analysis from 21 to 10 .

The $\beta$ for the pooled analysis for emerging market currencies is -0.028 . This estimate is significantly less than 1.0 at the $5 \%$ level. However we cannot reject the hypotheses that $\beta=0$. The coefficient for the pooled analysis for advanced economies is -2.023 (shown in graph below). Again, while we can reject the hypothesis $\beta=1$ at the 5\% level, and we can reject $\beta=0$ for the advanced economies, we cannot do so for the emerging markets. Increasing the ' $n$ ' leads us to a sharper difference in the estimated $\beta$ with a more negative value for the industrialized economies than for the emerging markets.

\begin{tabular}{|c|c|c|c|c|c|c|c|}
\hline Pooled Data & Dates & $N$ & $\begin{array}{c}\beta \\
(S . E .)\end{array}$ & $t: \beta=0$ & $t: \beta=1$ & $D W$ & FProb \\
\hline $\begin{array}{l}\text { Emerging } \\
\text { Economies }^{13}\end{array}$ & $12 / 96-4 / 04$ & 1014 & $\begin{array}{c}-0.0278 \\
(0.0290) \\
\end{array}$ & -0.96 & 1252 & 1.68 & 0.3375 \\
\hline $\begin{array}{l}\text { Advanced } \\
\text { Economies }^{14}\end{array}$ & $02 / 97-4 / 04$ & 780 & $\begin{array}{l}-2.0231 \\
(0.5426)\end{array}$ & -3.73 & 31.04 & 1.89 & 0.0002 \\
\hline
\end{tabular}

\footnotetext{
${ }^{13}$ Pooled Analysis of Emerging Economies does not include Indonesia. All dates are from 10/97 to 4/04.

${ }^{14}$ Pooled Analysis does not include the Euro countries. All dates are from 10/97 to 4/04.
} 


\begin{tabular}{|l|c|c|c|c|}
\hline \multicolumn{5}{|c|}{ TABLE V: Seemingly Unrelated Regressions (Pooled) } \\
\hline Pooled Data & Coef. & Std. Err. & $\boldsymbol{z}$ & $\boldsymbol{P}>|z|$ \\
\hline Emerging Market Economies & 0.15225 & 0.189572 & 0.80 & 0.422 \\
\hline & & & & \\
\hline Advanced Economies & -1.66551 & 0.450326 & -3.70 & 0.000 \\
\hline
\end{tabular}

\begin{tabular}{|l|c|c|c|c|c|}
\hline Equation & Obs & $\boldsymbol{R M S E}$ & $\mathrm{R}^{2}$ & $\chi 2$ & $\boldsymbol{P}$ \\
\hline Emerging Economies & 780 & .0254512 & -0.0004 & .6450539 & 0.4219 \\
\hline & & & & & \\
\hline Advanced Economies & 780 & .0280973 & 0.0220 & 13.67853 & 0.0002 \\
\hline
\end{tabular}

We also run Seemingly Unrelated Regressions in the pooled regression analysis to address cross-currency correlation. (See Table V.) The pooled SUR analysis dropped observations for the last three countries, alphabetically (Taiwan, Thailand and Turkey), to make the number of emerging market observations equal the advanced countries (ten currencies for each).

\section{Conclusions}

The regression analysis conducted in this paper produces a striking result. While the bias in the forward discount as a predictor of the future change in the spot exchange rate is present among emerging market currencies and advanced country currencies alike, the bias is less severe in the former case than in the latter. Unlike major currencies, which generally show a coefficient significantly less than zero, suggesting that the forward rate actually points in the wrong direction, the coefficient for emerging market currencies is on average slightly above zero, and even when negative is rarely significantly less than zero. One implication for traders is that the "yen carry trade" and "dollar carry trade" on average may not be as profitable when the strategy is to go long in emerging market currencies as when it is to go long in major currencies. An implication for international finance theorists, in light of the intuitively high riskiness of emerging currencies, is that the source of forward discount bias may not lie entirely in the exchange risk premium.

\footnotetext{
${ }^{15}$ Does not include Euro member countries (to avoid overlap of data with the Euro) and Indonesia (end date of available forward exchange rate data does not coincide with the data-sets available for the remaining countries)
} 


\section{$\underline{\text { References }}$}

Bacchetta, Philippe, and Eric van Wincoop, 2005, "Rational Inattention: A Solution to the Forward Discount Puzzle,” NBER WP no. 11633, September.

Backus, D., S. Foresi and C. Telmer, 2001, "Affine Models of Currency Pricing: Implications for the Forward Premium Anomaly," Journal of Finance, 56, 281-311.

Bansal, Ravi and Magnus Dahlquist, (2000), 'The forward premium puzzle: different tales from developed and emerging economies,' Journal of International Economics, Volume 51, 115-144.

Breuer, Janice Boucher, 2000, 'Term effects and time-varying risk premium in tests of forward foreign exchange rate unbiasedness,' International Journal of Finance and Economics, Vol. 5, 211-220.

Breuer, Janice Boucher, and Mark W. Wohar, 1996, 'The Road Less Traveled: Institutional aspects of data and their influence on empirical estimates with an application to tests of forward rate unbiasedness,' The Economic Journal, vol. 106, no. 434, $26-38$ (January).

Chinn, Menzie, and Jeffrey Frankel, 1994, "Patterns in Exchange Rate Forecasts for 25 Currencies," Journal of Money, Credit and Banking 26, no. 24, Nov., 759-770. Reprinted in New Developments in Exchange Rate Economics, edited by L. Sarno and M. Taylor, Edward Elgar Pub., 2002.

Chinn, Menzie, and Jeffrey Frankel, 2002, "Survey Data on Exchange Rate Expectations: More Currencies, More Horizons, More Tests," in Monetary Policy, Capital Flows and Financial Market Developments in the Era of Financial Globalisation: Essays in Honour of Max Fry, edited by David Dickinson and William Allen, Routledge, London and New York.

Engel, Charles, 1996, 'The forward discount anomaly and the risk premium: A survey of recent evidence,' Journal of Empirical Finance, Vol. 3, 123-192.

Fama, Eugene F., 1984, 'Forward and Spot Exchange Rates,' Journal of Monetary Economics, Volume 14, 319-338.

Flood, Robert, and Andrew Rose, 2002, "Uncovered Interest Parity in Crisis: The Interest Rate Defense in the 1990s," IMF Working Paper 01/207. IMF Staff Papers.

Frankel, Jeffrey, 1980, 'Tests of Rational Expectations in the Forward Exchange Rate Market,' 46, no. 4. April. (First draft, MIT, Jan. 1977.) Reprinted in On Exchange Rates, 1997, 189-205. (Cambridge: MIT Press).

Froot, Kenneth, and Richard Thaler, 1990, "Anomalies: Foreign Exchange," Journal of Economic Perspectives 4, June, 179-192.

Hansen, Lars Peter, and Robert J. Hodrick, 1980, 'Forward Exchange Rates as Optimal Predictors of Future Spot Rates: An Econometric Analysis,' The Journal of Political Economy, Volume 88, Number 5, 829-853 (October). 
Hodrick, Robert , 1987, The Empirical Evidence on the Efficiency of Forward and Futures Foreign Exchange Markets (New York: Taylor and Francis).

Huisman, Ronbald, Kees Koedijk, Clemens Kool, and Francois Nissen, 1998, "Extreme support for uncovered interest parity," Journal of International Money and Finance, vol 17, p. 211-228.

Lewis, Karen, 1995, "Puzzles in International Financial Markets," in Handbook of International Economics, vol. 3, G. Grossman and K. Rogoff, eds., North Holland, 1995.

Poonawala, Jumana, 2004, “Are Forward Exchange Rates Biased Indicators of Spot Exchange Rates in Emerging Market Economies?" Second Year Paper Analysis, Kennedy School of Government, Harvard University.

Lustig, Hanno, and Adrien Verdelhan (2005), "The Cross-Section of Currency Risk Premia and US Consumption Growth Risk,“ NBER WP 11104, February.

Rogoff, Kenneth. 1977. Rational expectations in the foreign exchange market revisited. Unpublished paper, MIT (February).

Tryon, Ralph. 1979. "Testing for rational expectations in foreign exchange markets," International Finance Discussion Paper no. 139. Federal Reserve Board (May).

Verdelhan, Adrien, 2006, "A Habit-Based Explanation of the Exchange Rate Risk Premium," April 2006. NBER Summer Institute, July. 
Figure 1: Spot on Forward Regression for Emerging Economies 12/1996 - 4/2003

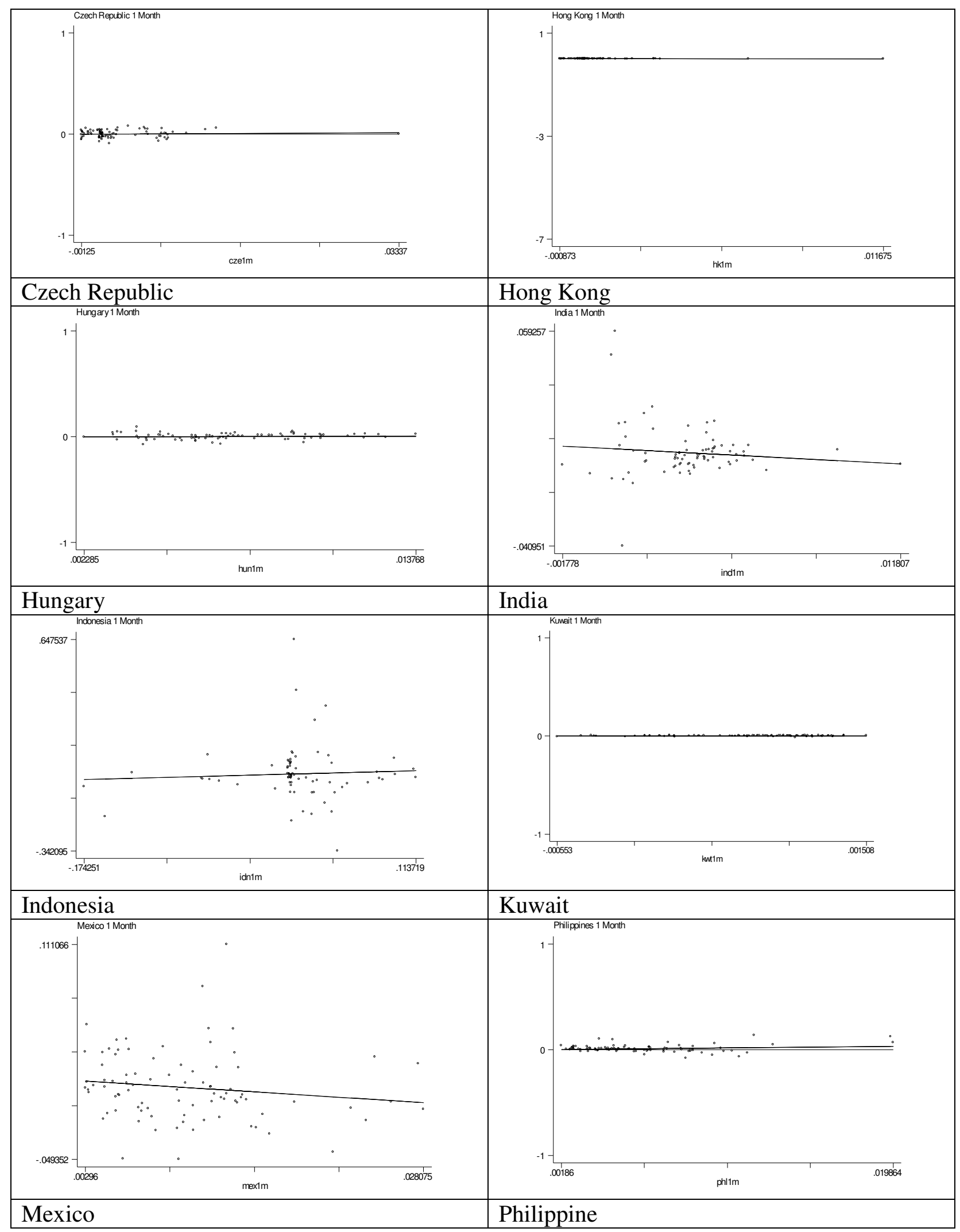



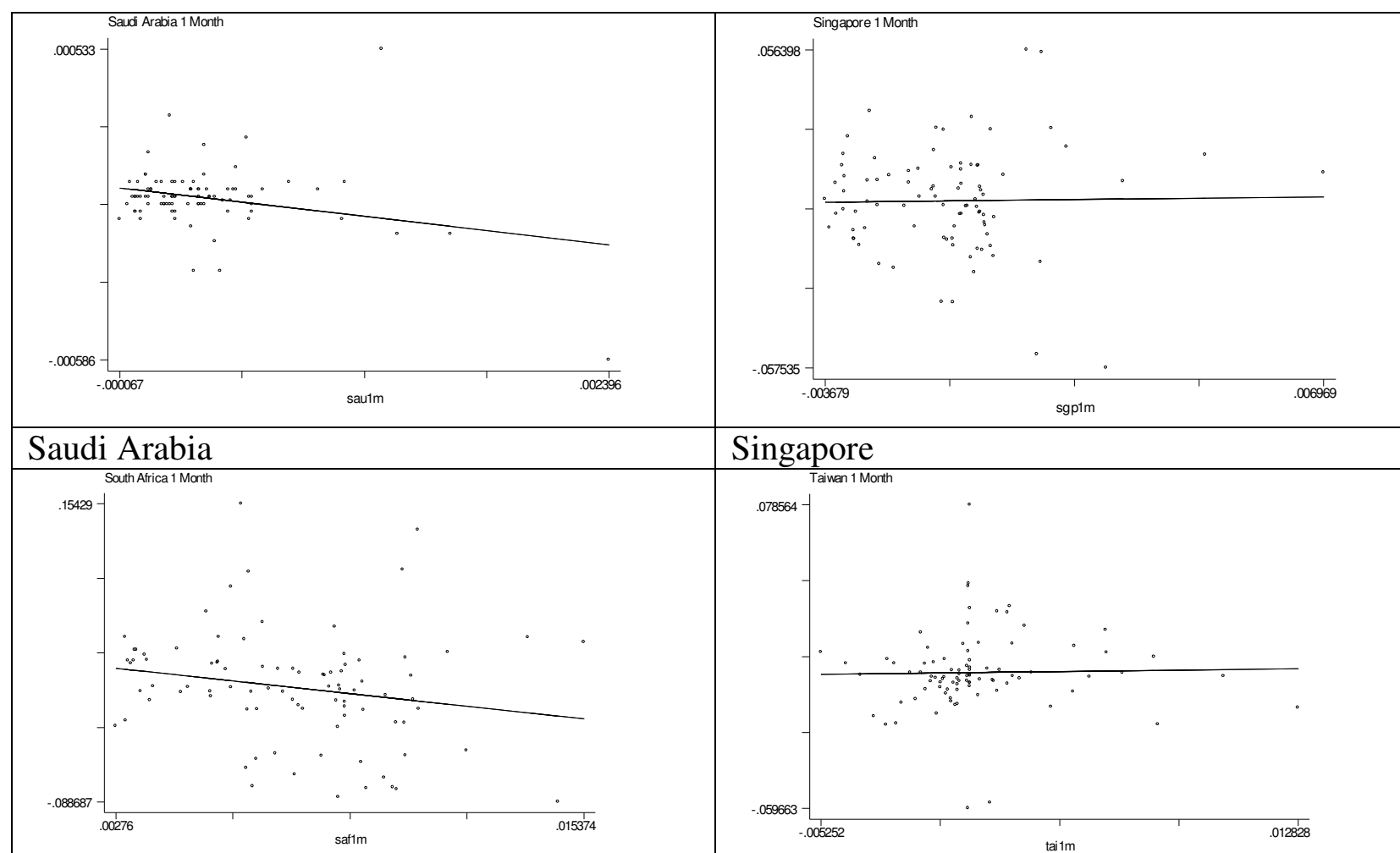

Singapore

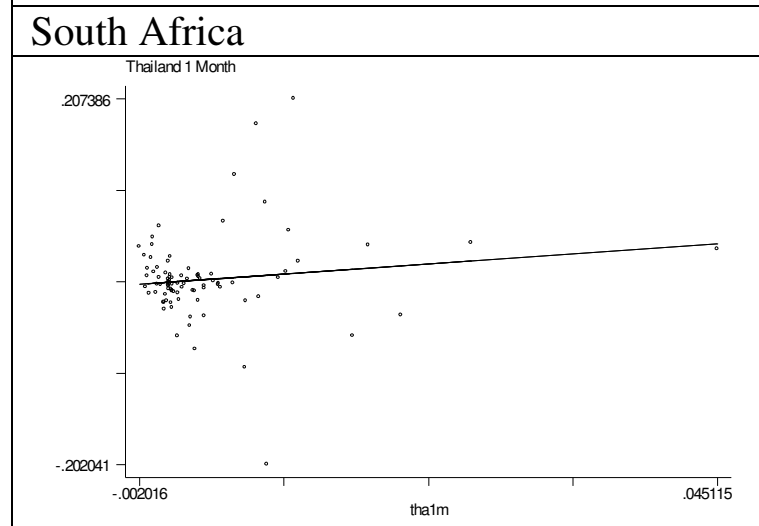

Thailand

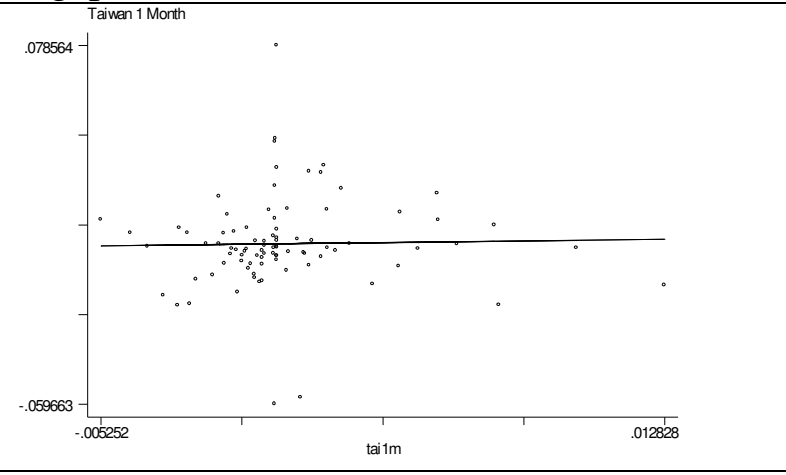

Taiwan

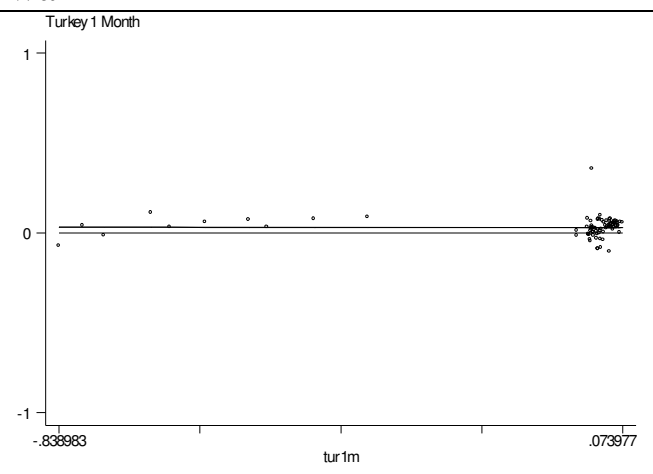

Turkey 
Figure 2: Spot on Forward Regression for Industrialized Economies 12/1996 $4 / 2003$

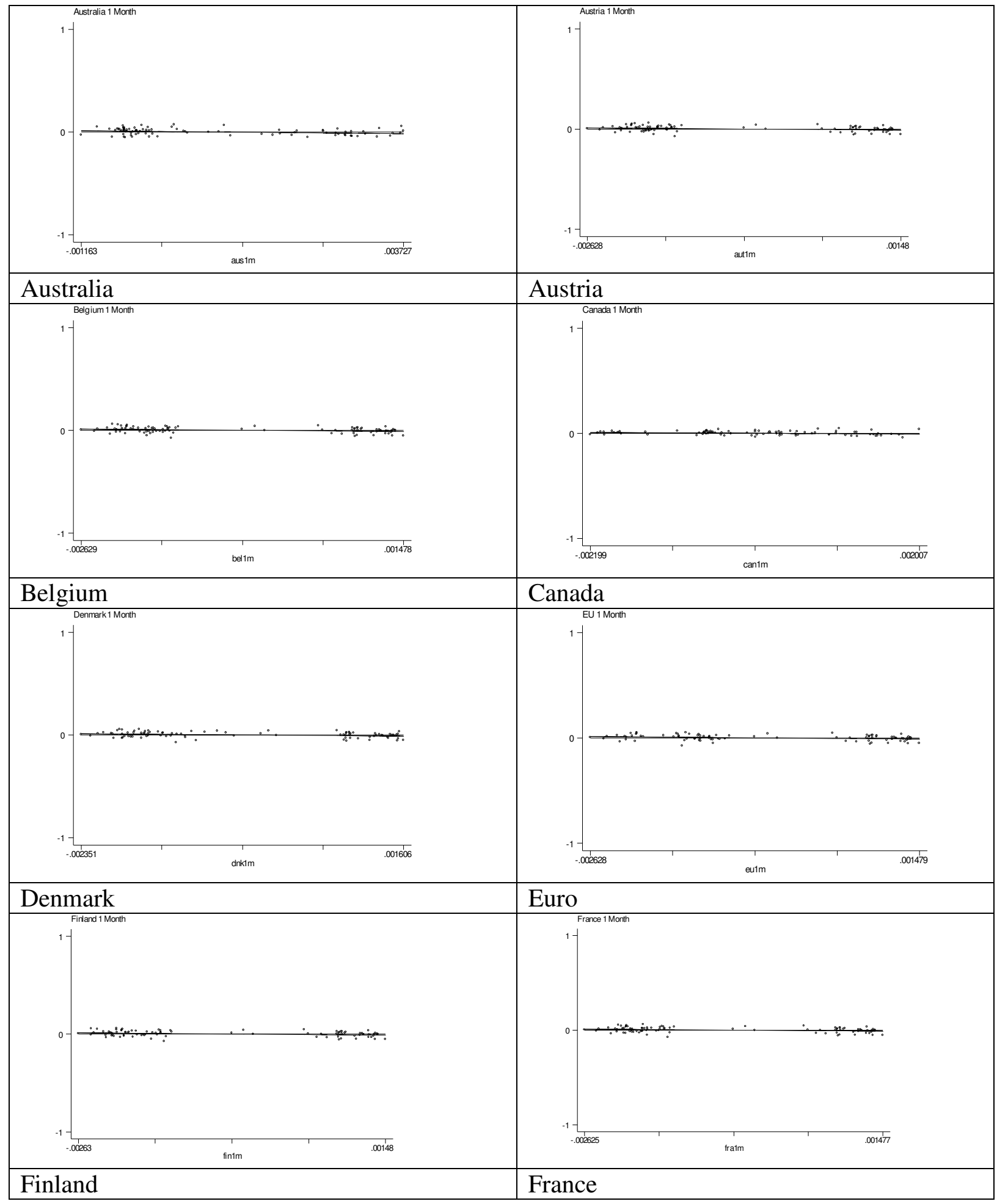




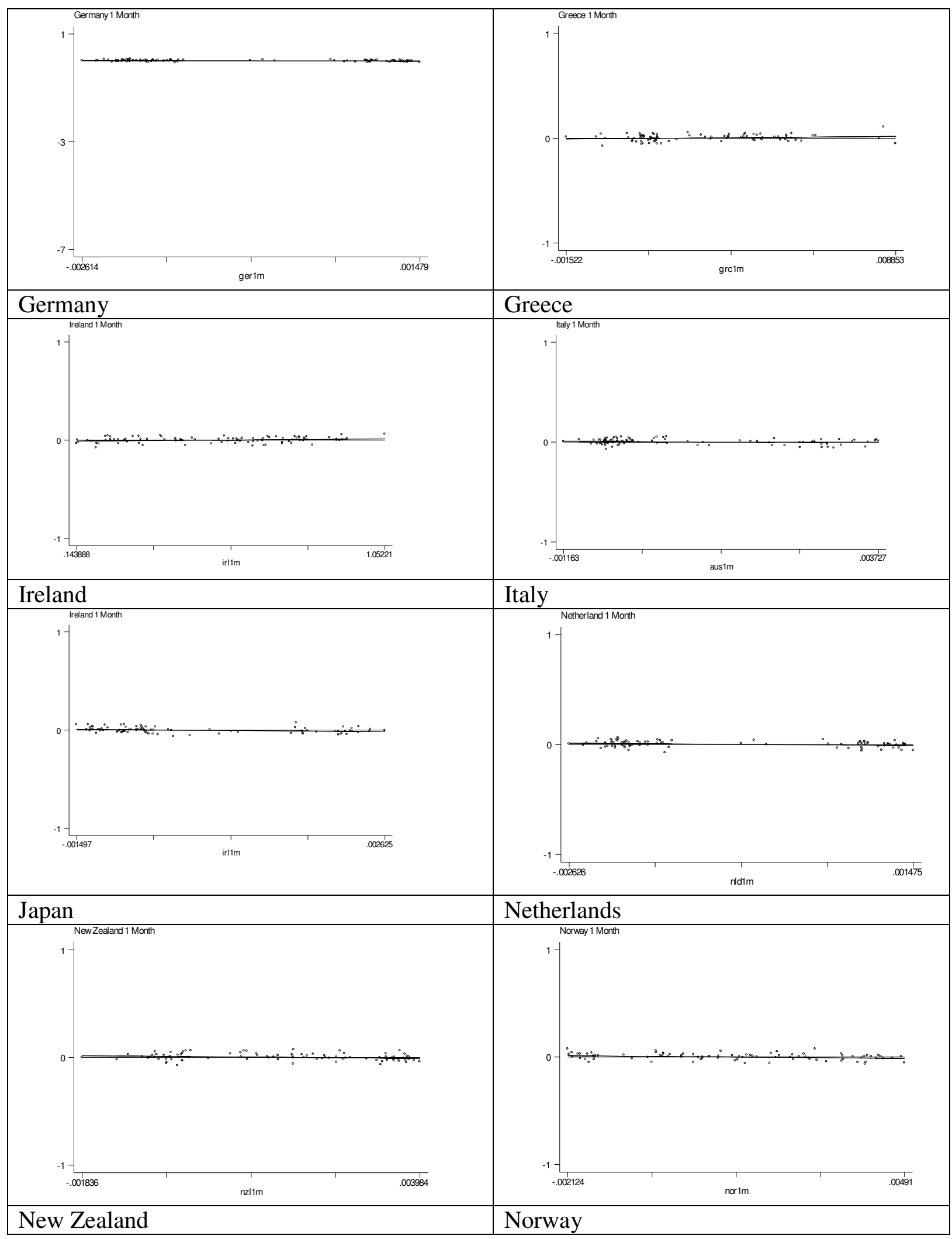




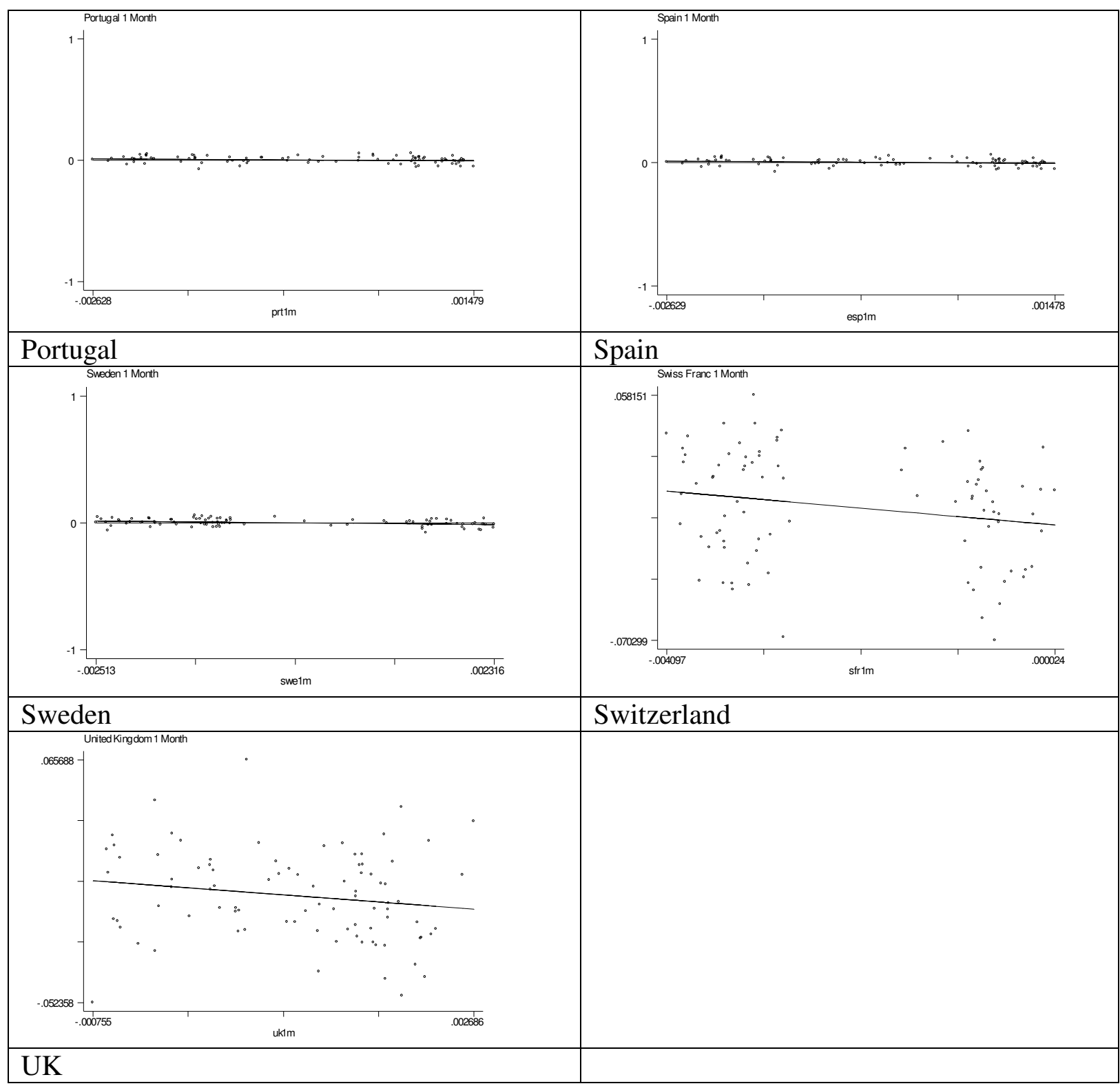


Figure 3: Pooled Analysis (including 13 emerging market currencies)

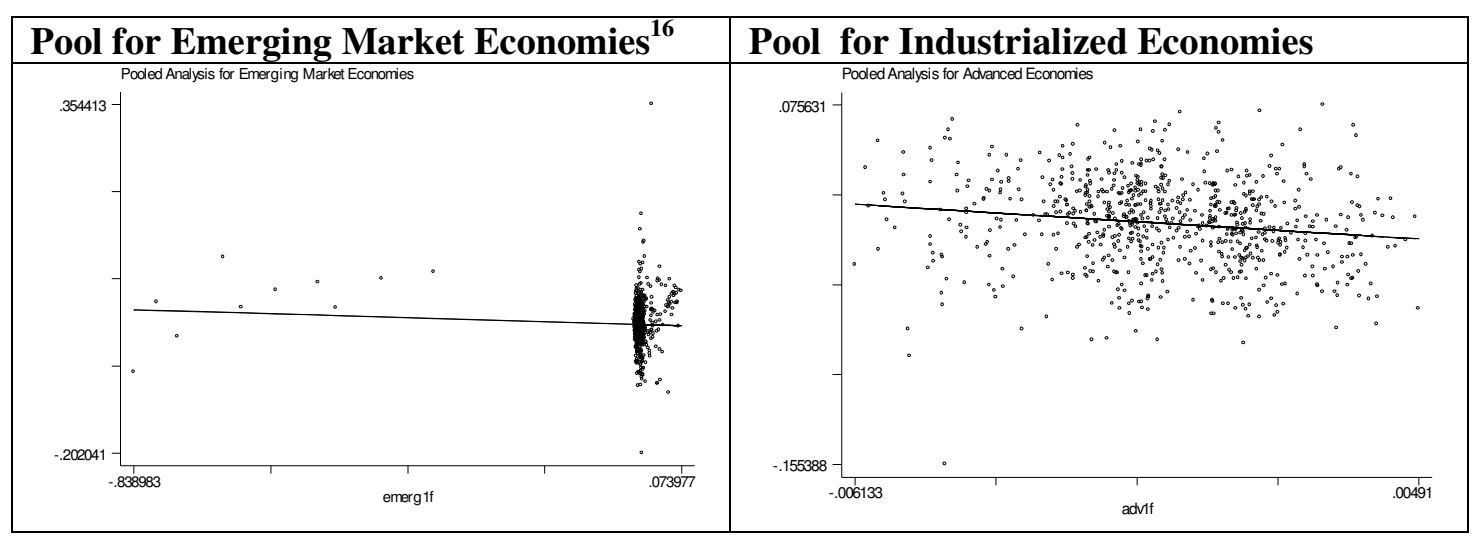

Figure 4: Pooled Analysis (10 currencies in each category)

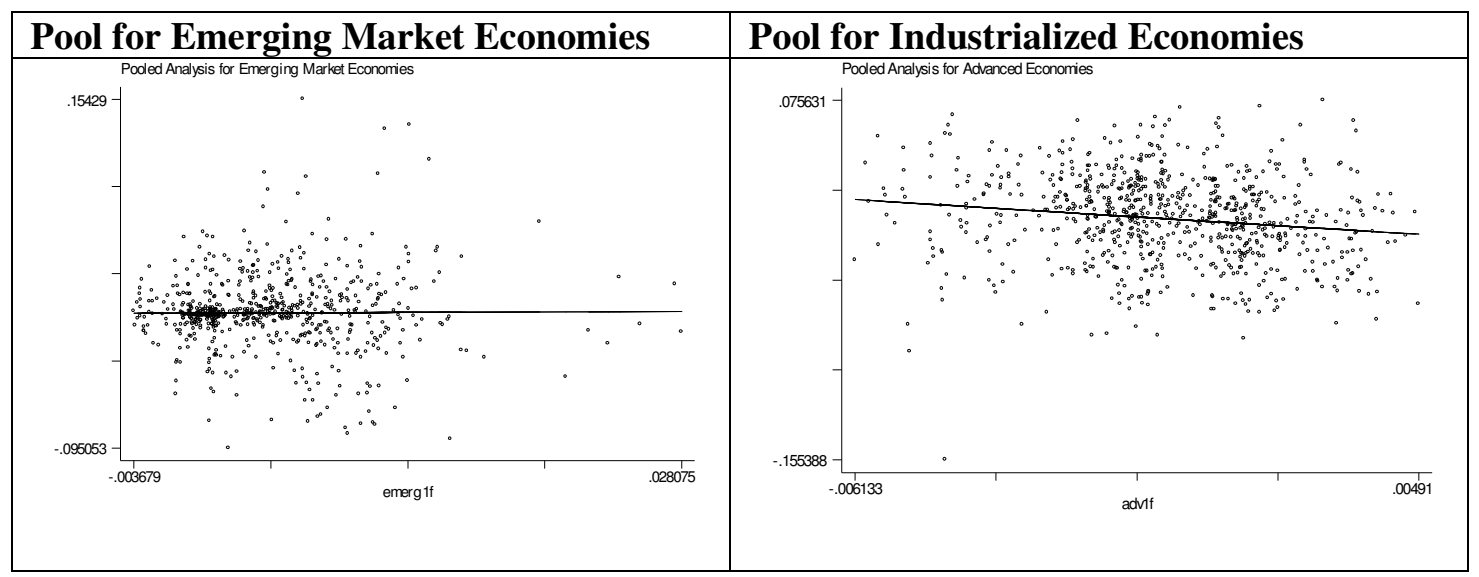

\footnotetext{
${ }^{16}$ A reason for the bimodal distribution of data in the emerging market graph is the observations from Turkey, where a large depreciation occurred in early 2001. (Appendix III and IV.)
} 


\section{APPENDICES: TABLE OF CONTENTS}

\section{DATA SET: Countries and currency dates}

TABLE I: Individual Country Regressions (12/31/98 - 08/30/2004)

- Omitting period of East Asia Crisis

TABLE II: $\quad$ Pooled Country Regressions (12/31/98 - 04/30/2003)

GRAPH I: $\quad$ Spot on Forward Regression for Emerging Economies (12/1998 5/2003) - Omitting period of East Asia Crisis

GRAPH II: Spot on Forward Regression for Industrialized Economies (12/1998 $-5 / 2003)$ - Omitting period of East Asia Crisis

\section{Data Set: Countries and currency dates}

\begin{tabular}{|c|c|c|c|}
\hline Forward Rates: & Start Date & End Date & Data Points \\
\hline Emerging Economies & & & (one-month) \\
\hline Hong Kong & $12 / 31 / 1996$ & $06 / 13 / 2003$ & 77 \\
\hline India & 07/29/1999 & $06 / 13 / 2003$ & $46^{*}$ \\
\hline Indonesia & $12 / 31 / 1996$ & $12 / 29 / 2000$ & $48^{* * *}$ \\
\hline Mexico & $12 / 31 / 1996$ & $06 / 13 / 2003$ & 77 \\
\hline Saudi Arabia & $12 / 31 / 1996$ & $06 / 13 / 2003$ & 77 \\
\hline Singapore & $12 / 31 / 1996$ & $06 / 13 / 2003$ & 77 \\
\hline South Africa & $12 / 31 / 1996$ & $06 / 13 / 2003$ & 77 \\
\hline Thailand & $12 / 31 / 1996$ & $06 / 13 / 2003$ & 77 \\
\hline Taiwan & $12 / 31 / 1996$ & $06 / 13 / 2003$ & 77 \\
\hline \multicolumn{4}{|c|}{ Industrialized Economies } \\
\hline Canada & $12 / 31 / 1996$ & $06 / 13 / 2003$ & 77 \\
\hline Euro & 02/21/1997 & $06 / 13 / 2003$ & $75 * * *$ \\
\hline Germany & $12 / 31 / 1996$ & $06 / 13 / 2003$ & 77 \\
\hline Japan & $12 / 31 / 1996$ & $06 / 13 / 2003$ & 77 \\
\hline Swiss Franc & $12 / 31 / 1996$ & $06 / 13 / 2003$ & 77 \\
\hline UK & $12 / 31 / 1996$ & $06 / 13 / 2003$ & 77 \\
\hline
\end{tabular}

Source: DataStream, Inc.

* Indian Forward Exchange Rates available as of 7/30/1999.

** Indonesian Forward Exchange Rates unavailable for the period 2/29/2001-11/29/2002.

*** EU Forward Exchange Rates available as of 2/28/1997. 
Individual Country Regressions (12/31/98 - 04/30/2003) -

Omitting period of East Asia Crisis

TABLE I: Individual Country Regressions (12/1998 - 4/2003)

Coefficients with Robust Standard Errors

$S_{t+1}-S_{t}=\alpha+\beta\left(F_{t}-S_{t}\right)+\varepsilon_{t}$

Forecast Horizon is One Month

\begin{tabular}{|c|c|c|c|c|c|c|c|}
\hline & Dates & $N$ & $\begin{array}{c}\beta \\
\text { (Std Error) }\end{array}$ & $t: \beta=0$ & $t: \beta=1$ & $D W$ & FProb \\
\hline \multicolumn{8}{|c|}{ Emerging Economies } \\
\hline Hong Kong & $12 / 98-4 / 03$ & 53 & $\begin{array}{l}0.0695 \\
(0.086) \\
\end{array}$ & 0.80 & 115.80 & 1.30 & 0.4249 \\
\hline India & $7 / 99-4 / 03$ & 46 & $\begin{array}{c}0.5347 \\
(1.0573) \\
\end{array}$ & 0.51 & 0.19 & 1.36 & 0.6156 \\
\hline Indonesia & $12 / 98-12 / 00$ & 24 & $\begin{array}{l}-1.306 \\
(1.916) \\
\end{array}$ & -0.68 & 1.45 & 2.20 & 0.5026 \\
\hline Mexico & $12 / 98-4 / 03$ & 53 & $\begin{array}{l}-1.196 \\
(0.826) \\
\end{array}$ & -1.45 & 7.06 & 1.96 & 0.1538 \\
\hline Saudi Arabia & $12 / 98-4 / 03$ & 53 & $\begin{array}{c}-0.0956 \\
(0.113) \\
\end{array}$ & -0.85 & 93.86 & 3.04 & 0.4017 \\
\hline Singapore & $12 / 98-4 / 03$ & 53 & $\begin{array}{l}-1.7859 \\
(1.589)\end{array}$ & -1.12 & 3.07 & 1.94 & 0.2665 \\
\hline South Africa & $12 / 98-4 / 03$ & 53 & $\begin{array}{l}-5.752 \\
(2.338)\end{array}$ & -2.46 & 8.34 & 1.66 & 0.0173 \\
\hline Taiwan & $12 / 98-4 / 03$ & 53 & $\begin{array}{c}0.423 \\
(0.670)\end{array}$ & 0.63 & 0.74 & 1.38 & 0.5308 \\
\hline Thailand & $12 / 98-4 / 03$ & 53 & $\begin{array}{l}-2.005 \\
(1.421)\end{array}$ & -1.41 & 4.47 & 2.04 & 0.1642 \\
\hline \multicolumn{8}{|c|}{ Industrialized Economies } \\
\hline Canada & $12 / 98-4 / 03$ & 53 & $\begin{array}{l}-5.87 \\
(3.50)\end{array}$ & -1.67 & 3.84 & 1.94 & 0.1002 \\
\hline Euro & $12 / 98-4 / 03$ & 53 & $\begin{array}{l}-6.87 \\
(2.29)\end{array}$ & -3.00 & 11.78 & 1.60 & 0.0042 \\
\hline Germany & $12 / 98-4 / 03$ & 53 & $\begin{array}{l}-6.88 \\
(2.29)\end{array}$ & -3.00 & 11.77 & 1.59 & 0.0042 \\
\hline Japan & $12 / 98-4 / 03$ & 53 & $\begin{array}{r}-1.039 \\
(2.18) \\
\end{array}$ & -0.48 & 0.87 & 1.85 & 0.6359 \\
\hline Switzerland & $12 / 98-4 / 03$ & 53 & $\begin{array}{l}-6.614 \\
(2.57) \\
\end{array}$ & -2.57 & 8.72 & 1.72 & 0.0133 \\
\hline UK & $12 / 98-4 / 03$ & 53 & $\begin{array}{r}-4.325 \\
(3.44) \\
\end{array}$ & -1.25 & 2.38 & 2.39 & 0.2155 \\
\hline
\end{tabular}

Note on DW Stat: For the test of null hypotheses (no autocorrelation) at the 5\% significance level, the appropriate $\mathrm{dL}$ and $\mathrm{dU}$ critical values for 53 observations and one explanatory valuable are 1.503 and 1.585 . In other words, we reject if $\mathrm{d}<1.503$ and do not reject if $\mathrm{d}>1.585$.

For 46 observations, $\mathrm{dL}=1.475$ and $\mathrm{dU}=1.566$

For 24 observations, $\mathrm{dL}=1.273$ and $\mathrm{dU}=1.446$ 
TABLE II: Pooled Country Regressions (12/1998-4/2003)

\begin{tabular}{|c|c|c|c|c|c|c|c|}
\hline & Dates & $N$ & $\begin{array}{c}\beta \\
(\text { Std Error })\end{array}$ & $t: \beta=0$ & $t: \beta=1$ & $D W$ & FProb \\
\hline $\begin{array}{l}\text { Emerging } \\
\text { Economies }^{17}\end{array}$ & $12 / 98-4 / 03$ & 371 & $\begin{array}{l}-0.3614 \\
(0.3348)\end{array}$ & -1.08 & 16.53 & 1.74 & 0.2812 \\
\hline $\begin{array}{l}\text { Industrialized } \\
\text { Economies }^{18}\end{array}$ & $12 / 98-4 / 03$ & 265 & $\begin{array}{l}-2.326 \\
(0.9172)\end{array}$ & -2.54 & 13.15 & 1.76 & 0.0118 \\
\hline
\end{tabular}

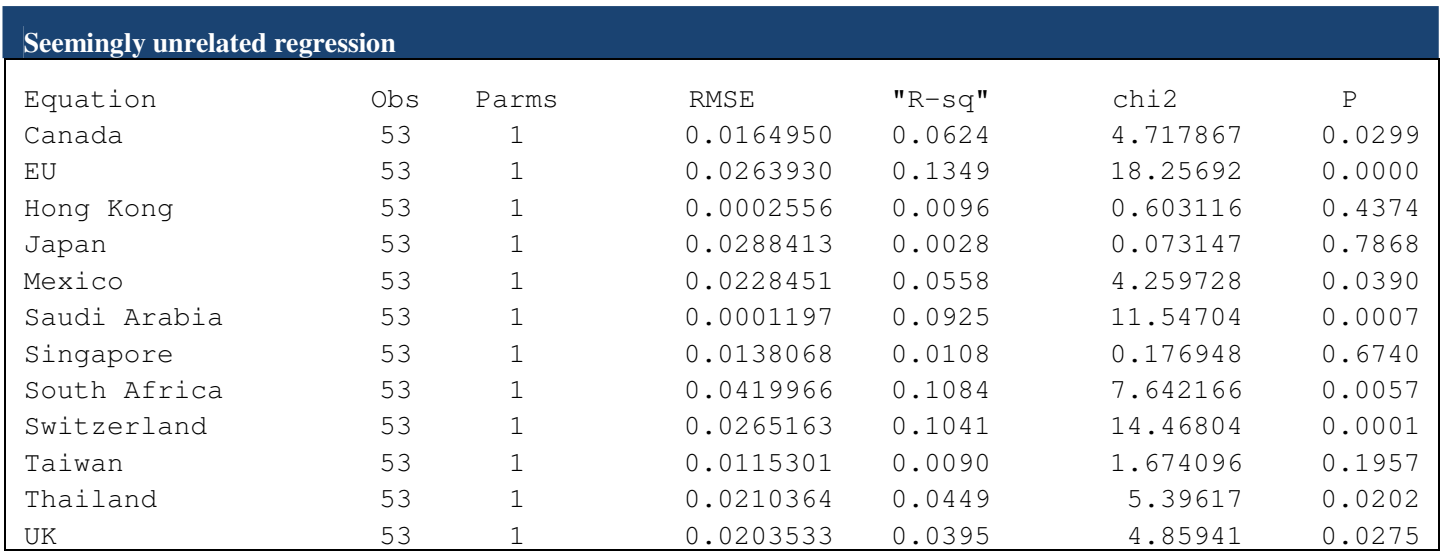

\begin{tabular}{|c|c|c|c|c|}
\hline & Dates & $B(S E)$ & $z$ & $P>/ z /$ \\
\hline \multicolumn{5}{|c|}{ Emerging and Newly Industrialized Economies } \\
\hline Hong Kong & $12 / 98-4 / 03$ & $\begin{array}{l}0.0707 \\
(0.910)\end{array}$ & 0.78 & 0.437 \\
\hline Mexico & $12 / 98-4 / 03$ & $\begin{array}{l}-1.2068 \\
(0.5847)\end{array}$ & -2.06 & 0.039 \\
\hline Saudi Arabia & $12 / 98-4 / 03$ & $\begin{array}{c}-0.1201 \\
(0.0353)\end{array}$ & -3.40 & 0.001 \\
\hline Singapore & $12 / 98-4 / 03$ & $\begin{array}{c}-0.5178 \\
(1.2311)\end{array}$ & -0.42 & 0.674 \\
\hline South Africa & $12 / 98-4 / 03$ & $\begin{array}{l}-5.8191 \\
(2.1050)\end{array}$ & -2.76 & 0.006 \\
\hline Taiwan & $12 / 98-4 / 03$ & $\begin{array}{c}0.5645 \\
(0.4363)\end{array}$ & 1.29 & 0.196 \\
\hline Thailand & $12 / 98-4 / 03$ & $\begin{array}{l}-2.1016 \\
(0.9047)\end{array}$ & -2.32 & 0.020 \\
\hline \multicolumn{5}{|c|}{ Industrialized Economies } \\
\hline Canada & $12 / 98-4 / 03$ & $\begin{array}{c}-5.8687 \\
(2.7019)\end{array}$ & -2.17 & 0.030 \\
\hline Euro & $12 / 98-4 / 03$ & $\begin{array}{l}-6.6151 \\
(1.5481)\end{array}$ & -4.27 & 0.000 \\
\hline Japan & $12 / 98-4 / 03$ & $\begin{array}{l}-0.5625 \\
(2.0801)\end{array}$ & -0.27 & 0.787 \\
\hline Switzerland & $12 / 98-4 / 03$ & $\begin{array}{l}-6.6025 \\
(1.7358)\end{array}$ & -3.80 & 0.000 \\
\hline UK & $12 / 98-4 / 03$ & $\begin{array}{l}-5.1323 \\
(2.3282)\end{array}$ & -2.20 & 0.027 \\
\hline
\end{tabular}

\footnotetext{
${ }^{17}$ Pooled Analysis of Emerging Economies does not include India or Indonesia to avoid errors due to correlation.

${ }^{18}$ To avoid double counting of data, pooled Analysis includes Canada, EU, Japan, Switzerland \& UK (12/98-4/03).
} 
Graph I: Spot on Forward Regression for Emerging Economies 12/1998 - 5/2003

-- Omitting period of East Asia Crisis

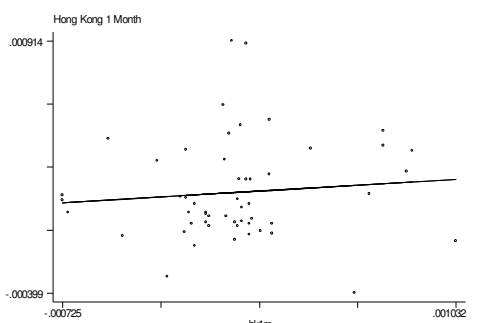

Hong Kong

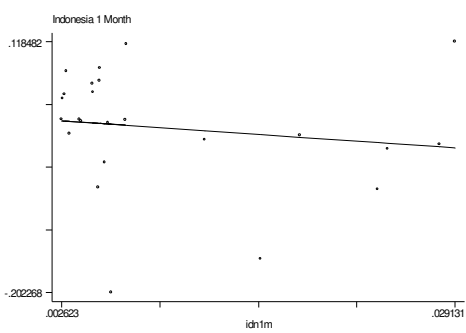

Indonesia

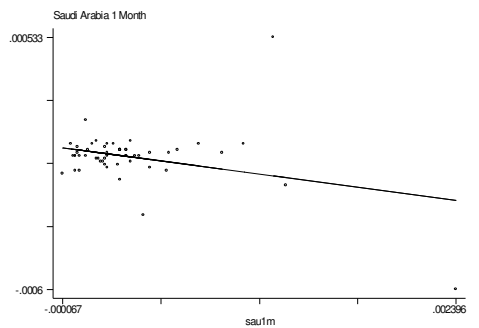

Saudi Arabia

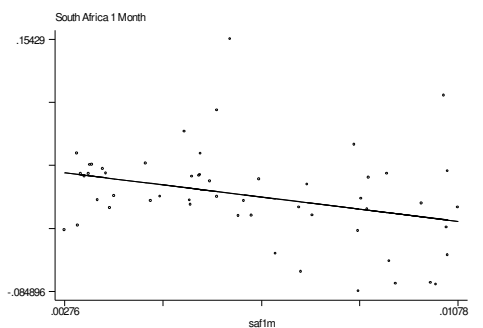

South Africa

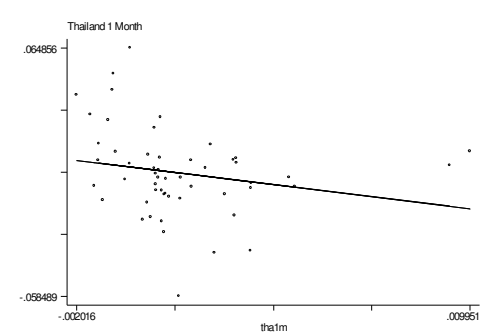

Thailand

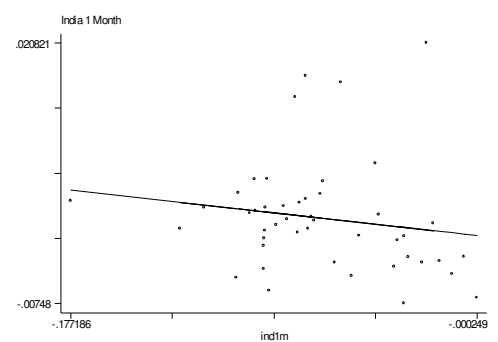

\section{India}

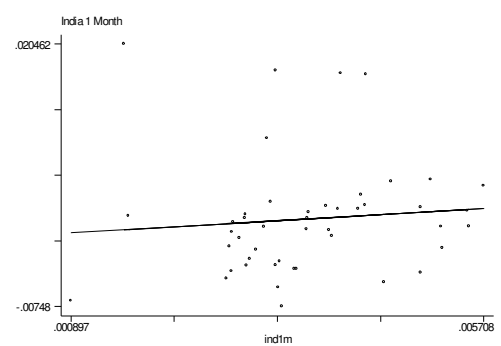

Mexico

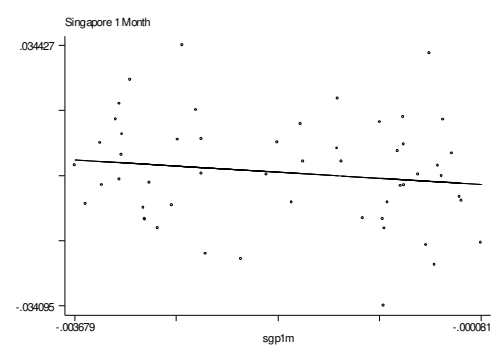

Singapore

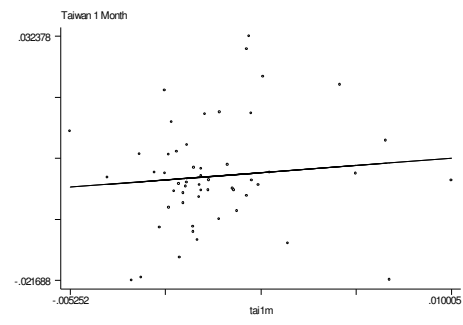

Taiwan 
Graph II: Spot on Forward Regression for Industrialized Economies 12/1998 - 5/2003

-- Omitting period of East Asia Crisis
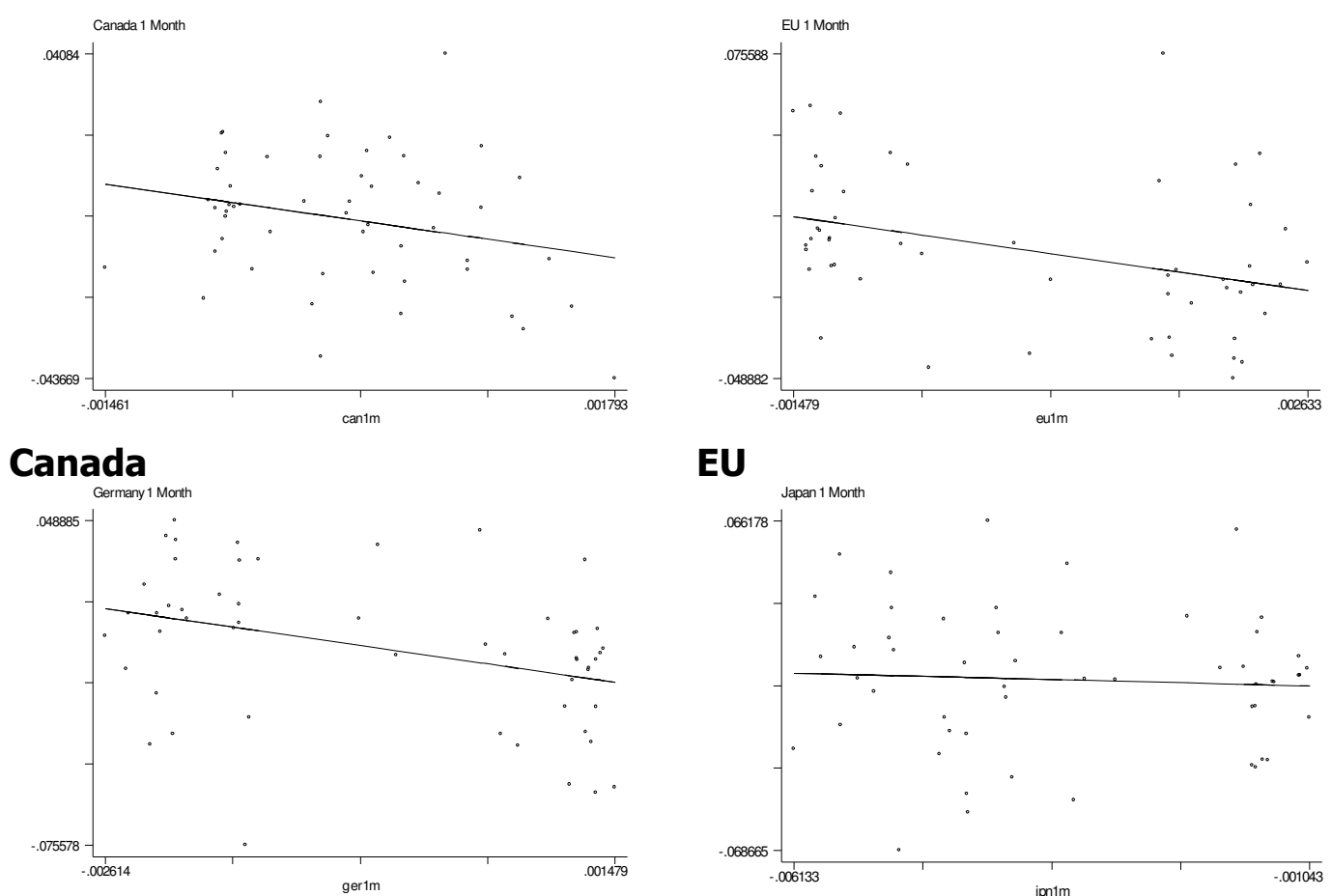

EU

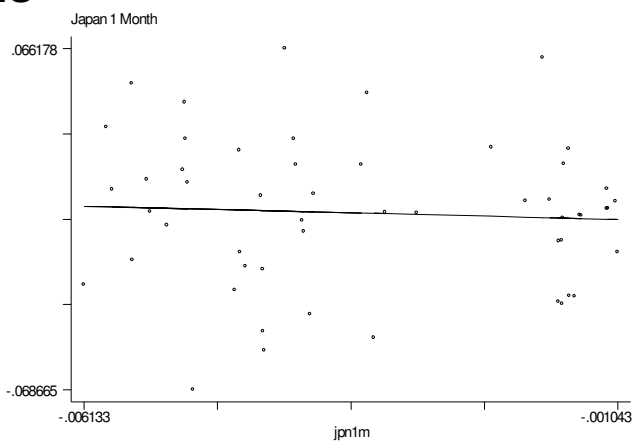

\section{Germany}

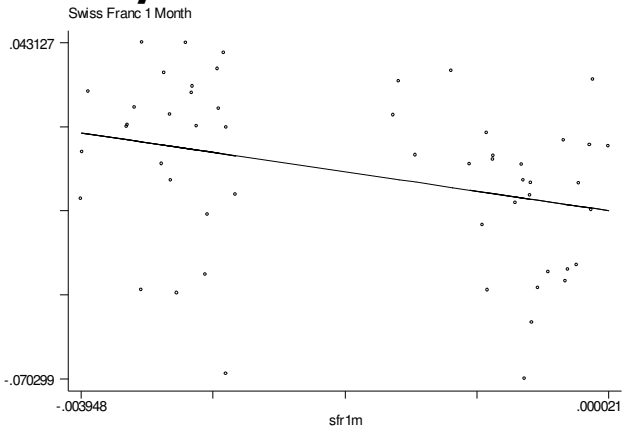

Swiss Franc

Japan

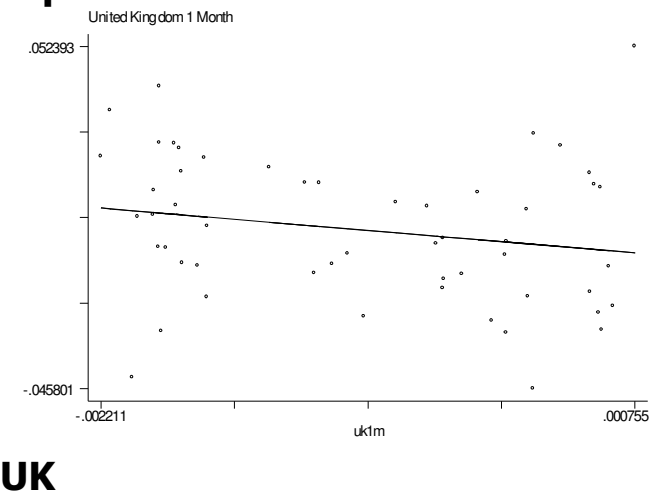


To order any of these papers in hard copy, see instructions at the end of this list. To subscribe to all NBER Working Papers or the papers in a single area, see instructions inside the back cover.

$\underline{\text { Number }}$

12447

12448

12449

12450

12452

12453

12454

12455

12456

12457

12458

12459

12460

12461 $\underline{\text { Author(s) }}$

Gary V. Engelhardt

Anil Kumar

Roberto Chang

Howard Kunreuther

Barry Eichengreen

David Leblang

Barry Eichengreen

Louis Kaplow

Dirk Krueger

Alexander Ludwig

Kenneth N. Kuttner

Naomi R. Lamoreaux

Jean-Laurent Rosenthal

Orazio P. Attanasio

Margherita Borella

Beata Smarzynska Javorcik

Wolfgang Keller

James Tybout

Philip DeCicca

Donald Kenkel

Alan Mathios

Yoon-Jeong Shin

Jae-Young Lim

James D. Adams

J. Roger Clemmons

Gayle J. Allard

Peter H. Lindert

Louis K.C. Chan

Stephen G. Dimmock

Josef Lakonishok
Title

$\underline{\text { Date }}$

Employer Matching and 401(k) Saving: Evidence From the8/06 Health and Retirement Study

Electoral Uncertainty and the Volatility of International8/06 Capital Flows

Reflections on U.S. Disaster Insurance Policy for the $21^{\text {st }} 8 / 06$ Century

Democracy and Globalization

$8 / 06$

Insurance Underwriter or Financial Development Fund: 8/06 What Role for Reserve Pooling in Latin America?

Myopia and the Effects of Social Security and Capital 8/06 Taxation on Labor Supply

On the Consequences of Demographic Change for Rates of 8/06 Returns to Capital, and the Distribution of Wealth and Welfare

Can Central Banks Target Bond Prices? 8/06

Contractual Tradeoffs and SMEs' Choice of Organizational8/06 Form: A View From U.S. and French History, 1830-2000

Stochatic Components of Individual Consumption: A Time 8/06 Series Analysis of Grouped Data

Openness and Industrial Response in a Wal-Mart World: 8/06 A Case Study of Mexican Soaps, Detergents, and Surfactant Producers

Youth Smoking, Cigarette Prices, and Anti-Smoking 8/06 Sentiment

Science and Industry: Tracing the Flow of Basic Research 8/06 Through Manufacturing and Trade

Euro-Productivity and Euro-Jobs Since the 1960s: Which 8/06 Institutions Really Mattered?

Benchmarking Money Manager Performance: Issues and 8/06 Evidence 
To order any of these papers in hard copy, see instructions at the end of this list. To subscribe to all NBER Working Papers or the papers in a single area, see instructions inside the back cover.

$\begin{array}{ll}\text { Number } & \text { Author(s) } \\ 12462 & \text { Thomas Philippon } \\ 12463 & \text { Alan J. Auerbach } \\ 12464 & \begin{array}{l}\text { Kevin Lang } \\ \text { Erez Siniver }\end{array} \\ 12465 & \begin{array}{l}\text { Steven N. Kaplan } \\ \text { Bernadette A. Minton }\end{array} \\ 12466 & \begin{array}{l}\text { Anne Case } \\ \text { Christina Paxson }\end{array} \\ 12467 & \text { Raj Chetty } \\ & \text { Adam Szeidl } \\ 12468 & \text { Jeff DeSimone } \\ 12469 & \text { Dhanoos Sutthiphisal }\end{array}$

Understanding International Portfolio Diversification and $8 / 06$ Turnover Rates

Competition, Innovation and Growth with Limited $\quad$ 8/06 Commitment

Modern Macroeconomics in Practice: How Theory is $\quad 8 / 06$ Shaping Policy

A Theory of Demand Shocks $\quad$ 8/06

First Do No Harm? Tort Reform and Birth Outcomes 8/06 
To order any of these papers in hard copy, see instructions at the end of this list. To subscribe to all NBER Working Papers or the papers in a single area, see instructions inside the back cover.

Number

12479

12480

12481

12482

12483

12484

12485

12486

12487

12488

12489

12490

12491

12492

12493 $\underline{\text { Author(s) }}$

Manuel Trajtenberg

Gil Shiff

Ran Melamed

Ellen Meara

Richard G. Frank

Ron Alquist

Menzie D. Chinn

Fernando A. Broner

Jaume Ventura

Giancarlo Corsetti

Luca Dedola

Sylvain LeDuc

M. Ayhan Kose

Eswar Prasad

Kenneth Rogoff

Shang-Jin Wei

Adam Ashcraft

Kevin Lang

Laarni Bulan

Christopher Mayer

C. Tsuriel Somerville

Urban J. Jermann

Daniel A. Ackerberg

Gautam Gowrisankaran

Craig Burnside

Martin Eichenbaum

Isaac Kleshchelski

Sergio Rebelo

Jennifer Hunt

Michael Bordo

Thomas Helbling

Harold James

Peter N. Ireland

Andrew B. Bernard

J. Bradford Jensen $\underline{\text { Title }}$

$\underline{\text { Date }}$

The "Names Game": Harnessing Inventors' Patent Data 8/06

for Economic Research

Welfare Reform, Work Requirements, and Employment 8/06 Barriers

Conventional and Unconventional Approaches to

$8 / 06$

Exchange Rate Modeling and Assessment

Globalization and Risk Sharing

$8 / 06$

Productivity, External Balance and Exchange Rates: 8/06

Evidence on the Transmission Mechanism

Financial Globalization: A Reappraisal

$8 / 06$

The Consequences of Teenage Childbearing

$8 / 06$

Irreversible Investment, Real Options, and Competition: 8/06

Evidence from Real Estate

The Equity Premium Implied by Production

$8 / 06$

Quantifying Equilibrium Network Externalities in the 8/06 ACH Banking Industry

The Returns to Currency Speculation

$8 / 06$

How Corruption Hits People When They Are Down 8/06

Swiss Exchange Rate Policy in the 1930s. Was the Delay 8/06 in Devaluation Too High a Price to Pay for Conservatism?

Changes in the Federal Reserve's Inflation Target: Causes 8/06 And Consequences

Transfer Pricing by U.S.-Based Multinational Firms $\quad$ 8/06 
To order any of these papers in hard copy, see instructions at the end of this list. To subscribe to all NBER Working Papers or the papers in a single area, see instructions inside the back cover.

\begin{tabular}{|c|c|c|c|}
\hline Number & $\underline{\text { Author(s) }}$ & $\underline{\text { Title }}$ & Date \\
\hline & Peter K. Schott & & \\
\hline 12494 & $\begin{array}{l}\text { Rebecca M. Blank } \\
\text { Heidi Shierholz }\end{array}$ & $\begin{array}{l}\text { Exploring Gender Differences in Employment and Wage } \\
\text { Trends Among Less-Skilled Workers }\end{array}$ & $8 / 06$ \\
\hline 12495 & $\begin{array}{l}\text { Linda Goldberg } \\
\text { Cédric Tille }\end{array}$ & $\begin{array}{l}\text { The International Role of the Dollar and Trade Balance } \\
\text { Adjustment }\end{array}$ & $8 / 06$ \\
\hline 12496 & $\begin{array}{l}\text { Jeffrey Frankel } \\
\text { Jumana Poonawala }\end{array}$ & $\begin{array}{l}\text { The Forward Market in Emerging Currencies: Less Biased } \\
\text { Than in Major Currencies }\end{array}$ & $8 / 06$ \\
\hline 12497 & $\begin{array}{l}\text { Gianmarco I.P. Ottaviano } \\
\text { Giovanni Peri }\end{array}$ & Rethinking the Effects of Immigration on Wages & $8 / 06$ \\
\hline 12498 & $\begin{array}{l}\text { Mark Gertler } \\
\text { Antonella Trigari }\end{array}$ & $\begin{array}{l}\text { Unemployment Dynamics With Staggered Nash Wage } \\
\text { Bargaining }\end{array}$ & $8 / 06$ \\
\hline 12499 & David W. Galenson & $\begin{array}{l}\text { A Conceptual World: Why the Art of the Twentieth } \\
\text { Century is so Different From the Art of All Earlier Centur }\end{array}$ & $\begin{array}{l}8 / 06 \\
\text { uries }\end{array}$ \\
\hline 12500 & $\begin{array}{l}\text { John Ammer } \\
\text { Sara B. Holland } \\
\text { David C. Smith } \\
\text { Francis E. Warnock }\end{array}$ & Look at Me Now: What Attracts U.S. Shareholders? & $8 / 06$ \\
\hline 12501 & $\begin{array}{l}\text { Luigi Guiso } \\
\text { Paola Sapienza } \\
\text { Luigi Zingales }\end{array}$ & The Cost of Banking Regulation & $8 / 06$ \\
\hline 12502 & $\begin{array}{l}\text { Gene Amromin } \\
\text { Jennifer Huang } \\
\text { Clemens Sialm }\end{array}$ & $\begin{array}{l}\text { The Tradeoff Between Mortgage Prepayments and Tax- } \\
\text { Deferred Retirement Savings }\end{array}$ & $8 / 06$ \\
\hline 12503 & $\begin{array}{l}\text { Howard Kunreuther } \\
\text { Mark Pauly }\end{array}$ & $\begin{array}{l}\text { Rules Rather Than Discretion: Lessons From Hurricane } \\
\text { Katrina }\end{array}$ & $8 / 06$ \\
\hline 12504 & $\begin{array}{l}\text { Bradley Herring } \\
\text { Mark V. Pauly }\end{array}$ & $\begin{array}{l}\text { The Effect of State Community Rating Regulations on } \\
\text { Premiums and Coverage in the Individual Health Insuran } \\
\text { Market }\end{array}$ & $\begin{array}{l}\text { 8/06 } \\
\text { nce }\end{array}$ \\
\hline
\end{tabular}

Copies of the above working papers can be obtained for $\$ 10.00$ per copy (plus $\$ 10.00$ per order for shipping for all locations outside the continental U.S.) to Working Papers, NBER, 1050 Massachusetts Avenue, Cambridge, MA 021385398. Pre-payment is required on all orders and may be made by check or credit card. Checks should be made payable to the NBER and must be in dollars drawn on a U.S. bank. If paying by credit card, include the cardholder's name, account number, and expiration date. For all orders, please be sure to include your return address and telephone number. Working papers may also be ordered by telephone (868-3900), fax (617-868-2742), or email (orders@nber.org). 